\title{
Knowledge of responsible technical nurses on management skills: a qualitative study
}

\author{
Conhecimento de enfermeiros responsáveis técnicos sobre competências gerenciais: um estudo qualitativo \\ Conocimiento de enfermeros responsables técnicos sobre competencias gerenciales: Un estudio cualitativo
}

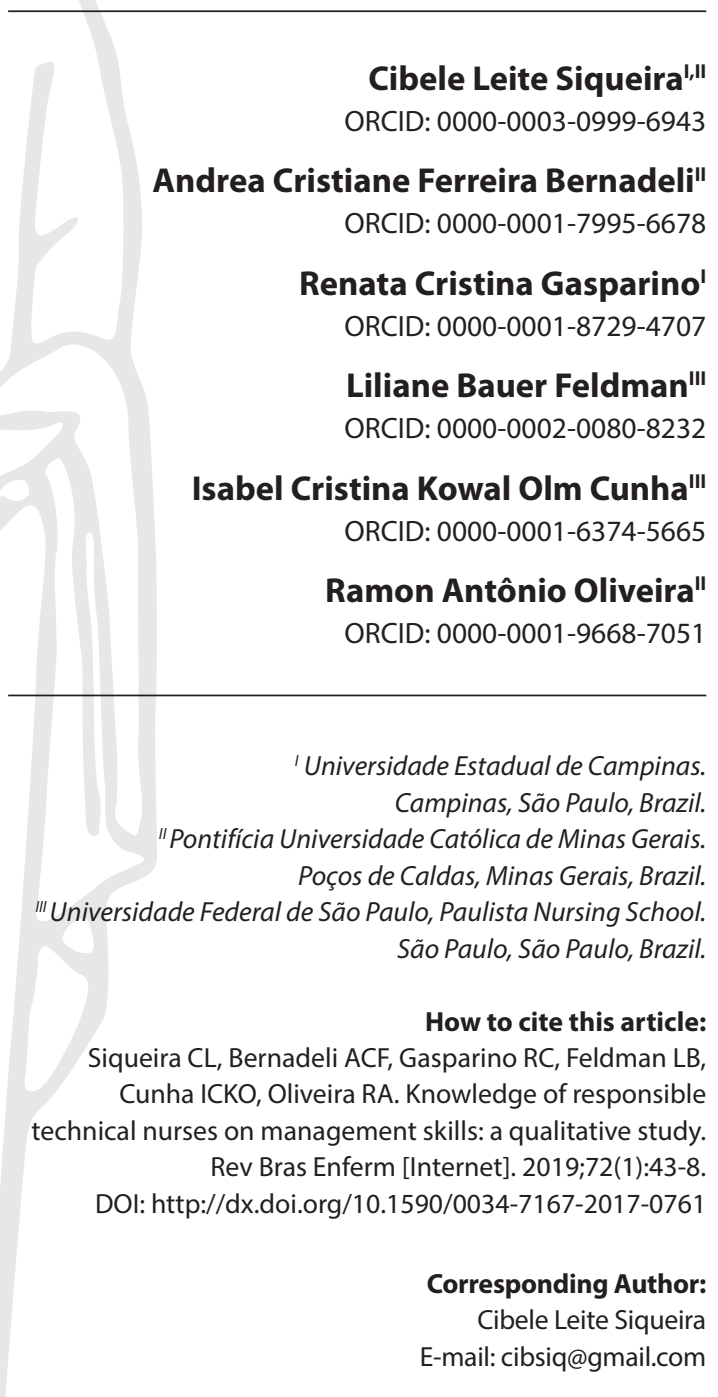

Submission: 10-25-2017

\section{ABSTRACT}

Objective: To identify the knowledge of responsible technical nurses in relation to the general and management skills required to perform this function. Method: Qualitative case study with 14 nurses. The semi-structured interviews were recorded and the data analyzed through the thematic content analysis. Results: Two categories stood out: Main Responsibilities for the Position of Technical Manager: Leadership, Interpersonal Relationship and Systemic view; and Developing Skills: Dissociation between Theory and Practice. Final considerations: The fact that only three skills have been recognized as necessary for the exercise of the function of technical leader and the perception of the interviewees about the dissociation between theory and practice during graduation should be explored by the teaching and health institutions, because to exercise this nurses must develop the technical-scientific, socio-educational and ethical-political skills to be able to lead the organization to positive results..

Descriptors: Knowledge; Nurses; Administrative Nurses; Professional Competence; Health Services Administration.

\section{RESUMO}

Objetivo: Identificar o conhecimento de enfermeiros responsáveis técnicos com relação às competências gerais e gerenciais necessárias para exercer esta função. Método: Estudo de caso qualitativo realizado com 14 enfermeiros. As entrevistas semiestruturadas foram gravadas e os dados analisados por meio da análise temática de conteúdo. Resultados: Duas categorias destacaram-se: Principais competências para se exercer o cargo de responsável técnico: liderança, relacionamento interpessoal e visão sistêmica e Desenvolvendo as competências: dissociação entre teoria e prática. Considerações finais: $O$ fato de apenas três competências terem sido reconhecidas como necessárias para o exercício da função de responsável técnico e a percepção dos entrevistados sobre a dissociação entre teoria e prática, durante a graduação, devem ser exploradas pelas instituições de ensino e saúde, pois para exercer esse cargo, o enfermeiro deve desenvolver as competências técnico-científica, socioeducativa e ético-política, para poder conduzir à organização a resultados positivos.

Descritores: Conhecimento; Enfermeiros; Enfermeiros Administradores; Competência Profissional; Administração de Serviços de Saúde.

\section{RESUMEN}

Objetivo: Identificar el conocimiento de enfermeros responsables técnicos con relación a las competencias generales y gerenciales necesarias para ejercer esta función. Método: Estudio de caso cualitativo realizado con 14 enfermeros. Las entrevistas semiestructuradas fueron grabadas y los datos analizados por medio del análisis temático de contenido. Resultados: Dos categorías se destacaron: Principales competencias para ejercer el cargo de responsable técnico: Liderazgo, relación interpersonal y visión sistémica; y Desarrollando las competencias: Disociación entre teoría y práctica. Consideraciones finales: El hecho de que sólo tres competencias hayan sido reconocidas como necesarias para el ejercicio de la función de responsable técnico y la percepción de los entrevistados sobre la disociación entre teoría y práctica durante la graduación, deben ser explotadas por las instituciones de enseñanza y salud, pues para ejercer ese papel el enfermero debe desarrollar las competencias técnico-científicas, socioeducativas y ético-políticas, para poder conducir a la organización a resultados positivos.

Descriptores: Conocimiento; Enfermeras; Enfermeros Administradores; Competencia Profesional; Administración de los Servicios de Salud. 


\section{INTRODUCTION}

Globalization, the incorporation of new technologies and the search for the quality of services have caused important changes in the work processes of healthcare institutions ${ }^{(1)}$.

Considering that in order to act in this demanding and competitive market, it is fundamental that professionals improve their skills to ensure a safe care for users $^{(2)}$ and that within the hospital institutions the nursing team is directly involved with most health care actions ${ }^{(1)}$, the Ministry of Education defined the skills that a graduate student in Nursing should develop throughout the course.

Competence means a set of knowledge, skills and attitudes that enable positive transformation of results $\mathrm{s}^{(3-4)}$. The six general skills described in the Brazilian Curriculum Guidelines (DCN - Diretrizes Curriculares Nacionais) include: Health Care; decision-making; Communication; leadership; administration and management; and Permanent Education ${ }^{(5)}$.

Authors demonstrate that the first competency to be acquired by the nurse is the scientific technician, described as Health Care in the DCN, in which the professionals develop actions of prevention, promotion, protection and rehabilitation of the health, at individual and collective level, based on scientific evidence ${ }^{(2,5-6)}$.

Secondly, socio-educational competence ${ }^{(6)}$, described as Permanent Education in the DCN should be developed, that is, it characterizes the professionals' ability to continually improve and share their knowledge in order to provide benefits to other professionals and institutions ${ }^{(5)}$.

The third and perhaps the most challenging competence to be developed by the nurse is the ethical-political, which consists of the professional's ability to build collective work processes; manage conflicts and make shared and ethical decisions in a supportive way. To do this, the nurse must incorporate skills in addition to those previously described, such as: Decision-making, communication, leadership, and administration and management ${ }^{(5)}$.

The requirement for the development of these skills is fundamental, as it is incumbent upon nurses to exercise, among other activities, supervision of the activities performed by nursing technicians and auxiliaries and the organization and direction of nursing services that are covered by the legislation that regulates the exercise of the profession ${ }^{(7)}$.

The direction of the nursing service implies the possession of a Certificate of Technical Responsibility, which configures the nurse Technically Responsible (TR) as the interlocutor between the institution and the Regional Nursing Council (COREN- Conselho Regional de Enfermagem) $)^{(8)}$.

In addition to being an interlocutor, the TR must ensure nursing care in an ethical and safe way ${ }^{(8)}$, integrate the assistance, administrative, teaching and research areas and, therefore, must know the interaction of the organizational processes to contribute to the success of the institution results ${ }^{(9)}$. Given such responsibility, it is expected that a TR will be competent in the three spheres described above: Technical-scientific, socio-educational and ethical-political.

Considering that the TR nurse should have skills beyond those described in the DCN, the COREN of São Paulo State (SP) developed a project that mapped 11 skills necessary for the performance of the TR nurse. Three are common to DCN (Leadership, Communication, Decision-Making) and the others include: Negotiation, teamwork, interpersonal relationships, flexibility, entrepreneurship, creativity, systemic view, and planning and organization $^{(10)}$. This set of skills is a reflection of the needs of the interrelation of the complexity of the activities developed by these professionals, social and legal demands.

The identification of the knowledge of TR nurses in relation to the skills required for the exercise of the position may contribute to the implementation of strategies in teaching and in the services where the professionals work, and can positively impact nursing care provided by professionals and institutions.

\section{OBJECTIVE}

This study aims to identify the knowledge of Technically Responsible nurses in relation to the general and management skills required to perform this function.

\section{METHOD}

\section{Ethical aspects}

The research was approved by the Research Ethics Committee of the Pontifícia Universidade Católica de Minas Gerais and was conducted according to the standards that regulate research involving human beings. To ensure anonymity, the study participants were named by the letter $\mathrm{N}$, corresponding to nurse, followed by the interview number.

\section{Type of setting and study}

It is a simple qualitative case study, which consists of the investigation of a phenomenon and its relation to the real life context, especially when the boundaries between the phenomenon and the context are not clearly evident ${ }^{(11)}$. The study was conducted in 14 medium and large hospitals, selected for convenience, located in five municipalities in the southern region of Minas Gerais State, 10 of which were private and four were public.

\section{Data source}

Each hospital selected had a single TR nurse and only one of the 15 was not included in the study, since those responsible for the institution did not authorize data collection. For the composition of the sample of 14 professionals, the following inclusion criteria were considered: Being a TR nurse and working at the institution for more than six months.

\section{Collection and organization of data}

Data collection was carried out between March and July 2015. A script based on the scientific literature containing sociodemographic issues (sex, age, professional training and time of experience) was drawn up, and the others had the purpose of guiding the interview semi-structured, namely: What are the management skills necessary to exercise the position of TR nurse? These skills were acquired during the undergraduate nursing course? 
The script was previously evaluated by two researchers in the area of administration in nursing. The pre-test was performed with two TR nurses linked to institutions not selected to conduct the study. For the data collection, the interviews were scheduled with the TR nurses and the interviewer went to the health institutions. Previously the accomplishment of the same, the objective of the study was presented and the participant's signature was obtained through the Free and Informed Consent Term. A single interview was conducted with each participant, recorded in a voice recorder, and the average time to perform them was approximately 11 minutes. At the end, the main topics reported were validated between the researcher and the interviewee, in order to guarantee the quality of the data collected.

\section{Data analysis}

The data were analyzed through the thematic analysis of content, which consisted of floating reading, constitution of the corpus, formulation and reformulation of hypotheses and objectives, exploitation of the material, treatment of results obtained and interpretation ${ }^{(12)}$.

\section{RESULTS}

The 14 TR nurses were predominantly female (92.9\%), the age range ranged from 20 to 50 years, and seven (50\%) professionals had between 31 and 40 years of age. As for training, 14 (100\%) professionals had Lato or Stricto Sensu Graduate courses, of which 10 (71.4\%) were experts and four (28.6\%) were masters. The majority (64.2\%) had between one and five years of training, ranging from one to 20 years.

In order to reach the research objective, after exhaustive reading of the collected data, two categories were listed: The first one refers to the grouping of the skills identified by the RTs as necessary for their professional performance, and the second one is related to the participants' reports on the dissociation between theory and practice, as regards the development of those skills, in other words, practice and professional experience as forms of learning.

Main Responsibilities for the Position of Technical Manager: Leadership, Interpersonal Relationship and Systemic view

Considering the skills described by the DCN and COREN/SP, it was possible to identify, from the participants' speech, only three skills as necessary for the practice of TR nurse: "leadership", "interpersonal relationship" and "systemic view". These skills were named, considering that each competency listed has an operational definition followed by guiding actions, that is, actions that reflect the practice of the described competence ${ }^{(10)}$.

In the speech of N5, the presence of the "leadership" competence is perceived ${ }^{(5,10)}$ when it is described the necessity of the TR to possess technical-scientific knowledge ${ }^{(10)}$ of the competence "systemic view", characterized by the capacity to understand the totality of the institution and the relationship between the parties and the competence "interpersonal relationship", defined as the ability to aggregate and interact with people in a cordial and professional way, with the aim of providing a favorable environment for the development of activities ${ }^{(10)}$ :

There is scientific technical knowledge, and an overview, on the part of the management, is to have the part of relationship, right? I think it is fundamental, [...]. (N5)

During the interview, N12 demonstrates the need for TR nurse to have the skills, "leadership"(5,10) and "interpersonal relationship"(10) expressed through actions such as promoting and encouraging cooperation between interdisciplinary teams and multiprofessional and development of the capacity to be accessible, respect and value individual differences in order to ensure humanized care to people ${ }^{(10)}$ :

A fundamental issue for TR, a humanistic vision [...] is really an articulator, the TR is the articulator, if he does not have a good relationship with all levels of the internal hierarchy, inside the hospital, or if he does not have a humanistic approach, if he is not true, this is noticed. (N12)

\section{Developing Skills: Dissociation between Theory and Practice}

This category is related to the fact that nurses believe that the skills required for the position described in the previous category were not fully developed during graduation. They reported that at this point in formation there is dissociation between what is learned in theory and what is experienced in practical activities and stages. In addition, it was possible to perceive that due to this lack of training, professionals end up improving the development of these skills in practice, that is, during the exercise of their professional activities.

In the speech of N4, it was observed that an important impeding factor in the performance of the function is related to the nondevelopment of these skills during the undergraduate course in Nursing, because there is dissociation between theory and practice:

[...] it is very helpful, and we had a class on how to scale, but nothing about following TR up, a TR day, to be in an internship with him, no, we did not have that contact. (N4)

When questioned about the development of management skills, it has been reported that this occurred over time, with professional experience associated with the desire to seek knowledge, as can be verified in the speech of a participant:

[...] It was with time, no one took my hand, nobody told me. It's just like that, we have to seek it, we have to go after it. Now, seeing from this perspective, are you prepared? Not for school, for life. [...]. (N2)

N9 reports his professional experience as a way of learning, he cites the theory that was offered him to acquire scientific knowledge, however, he emphasizes that the skill and the attitude were developed during the exercise of the position:

[...] I think this comes according to the experience, everything that we live in the environment, and professional maturity helps a lot; so the graduation gave me a base to support me, but the rest came from the environment itself, from the people themselves to help you to move on, and you also seek your goals [...]. (N9) 
N12 expresses in his speech the lack of training that comes from undergraduate training, regarding the acquisition of skills, pointing to a common example in the management by the nurse in health services:

It is counterproductive, because it did not really teach me, nor manage a unit cell service unit, in any way, the graduation is very poor, it is very insufficient, and I think to tell you the truth, we have been wrong since graduation [...] how am I going to want the nurse to know how to summon the employee if he has no skill if he has not developed the competence. Oh, he can learn, it can, it's true, but he will struggle a lot for it [...]. (N12)

\section{DISCUSSION}

The profile of the nurses in this study is very similar to another study carried out in the city of São Paulo, where most of the participants were also female and had some Graduate course, demonstrating the fulfillment of an ethical duty of these professionals in the search of completing their qualification ${ }^{(13)}$.

Considering the complexity and responsibility of the TR nurse role, it would ideally be that the professional selected for this role was prepared to perform it, and a troubling fact was that most participants identified only three skills, from the governs us and also by the DCN as necessary for the exercise of its function.

"Leadership" was the most cited competence, followed by "interpersonal relationship" and "systemic view". Leadership is classified as the most important competence for the exercise of the profession and to carry it out it is essential that effective communication is present when people are to be influenced in the pursuit of common objectives ${ }^{(14)}$.

Strong leadership contributes to teamwork and, consequently, to better results, as it reduces conflicts, increases employee involvement in work processes, improves resource utilization and decreases turnover rate ${ }^{(15)}$.

A satisfying interpersonal relationship involves communication, self-knowledge, empathy, cordiality, and ethics, which also significantly contributes to teamwork. The development of this competence is extremely complex, considering that the human being has feelings that interfere in the work environment and, therefore, the leader needs, as N12 said, to be the "articulator", to influence the parties involved in the processes, with the intention to make living together as harmonious as possible and, in this way, to achieve organizational objectives ${ }^{(15-16)}$.

With respect to the third competence identified by nurses, institutions today are interpreted as a sum of integral parts that depend on each other, have common goals and interact in an environment. In this way, the individual act does not have more space and the systemic view becomes more and more necessary. Therefore, the leader with systemic view must possess negotiation skills and know how to manage conflicts in order to maintain a good relationship among team members ${ }^{(17)}$.

A study conducted with administrators and managers of private and accredited hospitals classified, in order of importance, the skills deemed necessary for the performance of the manager's activities. For both, the most important choice was leadership. Next, for managers, teamwork and decision making were elected, and for managers, strategic vision and teamwork were elected. It can be observed similarity of these results with those found in the present study, where leadership and systemic view were also important skills for the performance of the function ${ }^{(18)}$.

It was possible to note that the three skills appointed by nurses have a close relationship with many others. The presence of one directly influences the performance of the other. However, the lack of recognition of these other skills by the participants makes us reflect on the criteria that are being adopted for the selection of these professionals. Authors report that the indication was the main criterion used in the selection of nursing managers, demonstrating that it is the performance history of this professional within the institution that contributed to their rise. They also reinforce that the skills presented by the professional up to the moment of their promotion may be very different from the skills necessary for the exercise of a new management position ${ }^{(13)}$. Therefore, it is important to use competency-based performance evaluations that use fair and clear instruments that can, in fact, contribute to the professional development, the achievement of the organizational goals and the sustainability of the system ${ }^{(19)}$.

According to the nurses interviewed, graduation provided a solid theoretical formation, that is, it provided the acquisition of knowledge of these skills, but it was not so effective in the development of skills and attitudes, which were acquired only during the exercise of the function.

There is a contradiction in the participants' speech, since, considering that the general skills pointed out by the DCN should be an integral part of the undergraduate nursing teaching projects ${ }^{(5)}$, and that the participants judged that they had received the theoretical content necessary to perform in the why did not they know how to name the skills?

One of the possible answers to this question may be that the sample has participants with 20 years of training and, therefore, did not experience these guidelines, however, the majority should have had contact with the topic, considering that they were formed after the implementation of the DCN and hold a position of extreme responsibility. It is known that the pedagogical projects of undergraduate courses in Nursing must be based on the assumptions contained in the DCN. However, research points out that some of them avoid this practice, which provokes the reformulation and reflection of the quality of these courses, since the idealization and planning of vocational training transcend the theoretical postulation and advances to the labor market, influencing the quality of training and, consequently, of the performance of the future professional ${ }^{(13)}$.

The Pedagogical Projects of the Courses must be linked to the Pedagogical Project of the educational institution, because if both do not reflect the same objectives and continue to use fragmented teaching methods, failing to transmit knowledge interprofessional and dissociating theory and practice, do not reflect the reality of the labor market, the student will have difficulties in establishing the fundamental relations for their formation and future performance as a professional ${ }^{(20)}$.

When analyzing the influence of the undergraduate in the preparation for the management in Nursing, the graduates of a public university reported difficulties in perceiving the management dimension in their work processes. Likewise, they reported 
difficulties in developing management competence in their professional practice ${ }^{(21)}$.

In the context of the training of nurses for the world of work, it is known that the teaching of the management discipline in nursing is of unique relevance in the professional training for the management performance, in the different levels of Health Care ${ }^{(9)}$. On the other hand, it is known that the teaching of management skills in undergraduate courses is not a simple task and therefore requires permanent efforts by both teachers and students ${ }^{(18)}$. Thus, professional training linked to the needs of work in the world of work plays an important role $\mathrm{e}^{(22)}$.

By assuming that the undergraduate did not offer all the necessary input of skills and attitudes necessary for the performance of the position, it was possible to note, through the accomplishment of the Graduate courses, the effort and commitment of these professionals with their Permanent Education. However, the quality of these Graduate courses is also questioned, because although they were not specifically addressed, in no speech was the importance of Graduate in the development of management skills.

It should be emphasized that, in general, the curricular subjects of undergraduate Nursing courses address the basic concepts about management and point out the guidelines for the accomplishment of such processes. Faced with this fact, it is the teacher's role to discuss with the student, within health institutions, the relationship between theory and management practice. In this way, the student will broaden the understanding of the skills and attitudes required to manage services, reducing the dissociation between theory and practice, as reported by professionals ${ }^{(23)}$.

The teacher should also awaken in the student the understanding that the full development of management skills is not possible during graduation due to the duration of the courses, interest and maturity of the student for the learning and that these skills can be constructed and improved in different ways, including after the entry of the professional in the labor market, through participation in discussions between students and teachers in the workplace, participation in research groups on the subject, participation in Graduate courses with recognized quality and development programs professional. It is of extreme importance that the professional's responsibility to continually update himself is always emphasized by the teachers ${ }^{(23)}$.

Facing this setting, it is necessary that teachers of undergraduate and Graduate courses, as well as nurses responsible for the services of Permanent Education of health institutions, review the means and methods of teaching, noting that these difficulties can be overcome as far as possible. in which there is greater interest of the parties involved, which also includes the interest of the professional with his own development ${ }^{(24)}$.

In addition, it is important that the institutions establish the competency profile expected for the one who performs the TR function, since, therefore, those who work in Permanent Education will have the tools to base the training necessary for the individual and collective development of these professionals. Allied to this, the training centers should use teaching strategies, so as to bring them closer to the problems of practice, creating situations in which, in fact, the skills required for nurses to be effectively developed ${ }^{(25)}$.
It is suggested that educational institutions use research that addresses the topic of Management Skills, to guide the construction and/or reform of pedagogical projects, investing efforts to associate theoretical and practical teaching with the demands of the Brazilian Unified Health System (Sistema Único de Saúde) and health care institutions and that health institutions map out the skills needed to perform each function, so that they can promote training that contributes to the improvement of the professionals' skills and, consequently, to the achievement of organizational goals.

\section{Study limitations}

The fact that the research was carried out in only one macroregion of the Brazilian state, the same compromises the generalization of the data to the national reality and, therefore, new studies are necessary so that the knowledge of the TR nurses can be divulged with respect the skills needed to develop their practice in the most different Brazilian states.

\section{Contributions to the sector of Nursing}

This research contributes to encourage the critical reflection on the training and knowledge of nurses who currently occupy strategic positions within the health organizations with regard to the skills necessary for their professional performance.

This topic must be explored by educational and health institutions, since a nurse, in order to achieve a position of TR, must have developed the technical-scientific, socio-educational and the most challenging skills, ethical-political, to be able to lead the organization to positive results.

\section{FINAL CONSIDERATIONS}

Although only three skills (leadership, interpersonal relationship and systemic view) have been reported by the nurses of this study as being necessary to perform as a TR, these skills are fundamental for the exercise of the function. Emphasis is placed on the experience gained from practicing professional practice as the greatest facilitator in the development of these skills for the position.

According to the interviewees, the undergraduate courses in a short time contributed to the development of management skills of these professionals, so it is expected that this study contributes to the review of the pedagogical projects and objectives of the disciplines of Administration of undergraduate courses in Nursing; implementation of institutional development programs and the interest of professionals in continuously improving and developing their knowledge, whether through well-qualified Graduate courses and/or insertion in research groups and research on management issues.

\section{FUNDING}

Project financed by the Fund to encourage Research-FIP from Pontifícia Universidade Católica de Minas Gerais. 


\section{REFERENCES}

1. Vituri DW, Évora YDM. Total quality management and hospital nursing: an integrative literature review. Rev Bras Enferm [Internet]. 2015 [cited 2017 Aug 08];68(5):660-7. Available from: http://dx.doi.org/10.1590/0034-7167.2015680525i

2. Salum NC, Prado ML. Continuing education in the development of competences in nurses. Text Context Nursing [Internet]. 2014 [cited 2017 Aug 03];23(2):301-8. Available from: http://dx.doi.org/10.1590/0104-070720140021600011

3. Sade PMC, Peres AM, Wolff LDG. The formation of the managerial competences of nurses: an integrative review. J Nurs UFPE Online [Internet]. 2014 [cited 2017 Aug 03];8(6):1739-45. doi: 10.5205/reuol.5876-50610-1-SM.0806201438

4. Camelo SHH, Angerami ELS. Professional competence: the building of concepts and strategies developed by health services and implications for nursing. Text Context Enferm [Internet]. 2013 [cited 2017 Aug 03];22(2):552-60. Available from: http://dx.doi.org/10.1590/ S0104-07072013000200034

5. Conselho Nacional de Educação, Câmara de Educação Superior. Resolução CNE/CES no. 3 de 7 de novembro de 2001. Institui as Diretrizes Curriculares Nacionais do Curso de Graduação em Enfermagem. [Internet]. Diário Oficial da União: república Federativa do Brasil; 2001 [cited 2018 Nov 3]. Nov 9, Seção 1: [about 6 screens]. Available from: http://portal.mec.gov.br/cne/arquivos/pdf/CES03.pdf

6. Meira MDD, Kurcgant P. Political-ethical skill development in nursing undergraduates. Rev Esc Enferm USP [Internet]. 2013 [cited 2017 Aug 03];47(5):1203-10. Available from: doi:10.1590/S0080-623420130000500027

7. Conselho Federal de Enfermagem (COFEN). Lei n. 7.498, de 25 de junho de 1986. Dispõe sobre a regulamentação do exercício da Enfermagem e dá outras providências [Internet]. Diário Oficial da União: República Federativa do Brasil; 1986 [cited 2018 Nov 3]. Jun 26, Seção 1: [about 9 screens]. Available from: http://www.cofen.gov.br/lei-n-749886-de-25-de-junho-de-1986_4161.html

8. Conselho Federal de Enfermagem (COFEN). Resolução no. 509 de 15 de Março de 2016. Atualiza a norma técnica para Anotação de Responsabilidade Técnica pelo Serviço de Enfermagem e define as atribuições do enfermeiro Responsável Técnico [Internet]. Diário Oficial da União: República Federativa do Brasil; 2016 [cited 2018 Nov 3]. Seção 1: [about 4 screens]. Available from: http://www.cofen.gov.br/ resolucao-cofen-no-05092016-2_39205.html

9. Almeida ML, Peres AM, Bernardino E, Santos MF. [Graduates of a public university and perspectives of performance in nursing management]. Rev Rene [Internet]. 2014 [cited 2017 Aug 03];15(6):933-41. Available from: doi:10.15253/2175-6783.2014000600005 Portuguese.

10. Conselho Regional de Enfermagem de São Paulo (COREN-SP). Projeto Competências. São Paulo: COREN-SP; 2009. 16 p.

11. Yin RK. Estudo de caso: planejamento e métodos. 4 ed. Porto Alegre: Bookman; 2010. 248 p.

12. Minayo MCS. O desafio do conhecimento: pesquisa qualitativa em saúde. 14 ed. São Paulo: Hucitec; 2014. 416 p.

13. Furukawa PO, Cunha ICKO. [Profile and competencies of nurse managers at accredited hospitals]. Rev Latino-Am Enferm [Internet]. 2011 [cited 2018 Feb 09];19(1):106-14. Disponível em: http://www.revistas.usp.br/rlae/article/view/4295/5477 Portuguese.

14. Okagawa FS, Bohomol E, Cunha ICKO. Competencies developed in a nursing management distance learning specialization course. Acta Paul Enferm [Internet]. 2013 [cited 2018 Feb 09]; 26(3):238-44. Available from: http://dx.doi.org/10.1590/S0103-21002013000300006

15. Lanzoni GMM, Meirelles BHS. Leadership of the nurse: an integrative literature review. Rev. Latino-Am. Enferm [Internet]. 2011 [cited 2018 Feb 09];19(3):651-8. Available from: http://dx.doi.org/10.1590/S0104-11692011000300026

16. Cardozo CG, Silva LOS. [The importance of interpersonal relationships in the workplace]. Interbio [Internet]. 2014 [cited 2018 Feb 09];8(2):24-34. Available from: http://www.unigran.br/interbio/paginas/ed_anteriores/vol8_num2/arquivos/artigo3.pdf Portuguese.

17. Alves HP. Congresso Virtual Brasileiro de Administração. A importância da visão sistêmica no gerenciamento de equipes em projeto [Internet]. In: X Congresso Virtual Brasileiro de Administração. 2012 [cited 2018 Feb 09]. [place unknown]: [publisher unknown]; 9 p. Available from: http://www.convibra.com.br/upload/paper/2012/34/2012_34_4830.pdf

18. Peres AM, Ezeagu TNM, Sade PMC, Souza PB, Gómez-Torres D. Mapping competencies: identifying gaps in managerial nursing training. Texto Contexto Enferm [Internet]. 2017 [cited 2017 Sep 01];26(2):e06250015. Available from: http://dx.doi. org/10.1590/0104-07072017006250015

19. Pereira NMD, Moreira V. [Nursing professionals performance appraisal: perception of justice of ratees]. Pensar Enferm [Internet]. 2015 [cited 2018 Feb 09];19(2):18-53. Available from: http://pensarenfermagem.esel.pt/files/doc2_18_53(5).pdf Portuguese.

20. Barros WM, Alves N, Menezes JR de, Mello-Carpes PB. [Educational seminars: basic subjects with professional practice tool of approach]. Rev Ciênc Ext [Internet]. 2012 [cited 2017 Aug 08];8(3):127-41. Available from: http://ojs.unesp.br/index.php/revista_proex/article/view/722/749 Portuguese.

21. Almeida ML, Peres AM, Bernardino E, Santos MF. [Graduates of a public university and perspectives of performance in nursing management]. Rev Rene [Internet]. 2014 [cited 2018 Feb 09];15(6):933-941. Available from: doi:10.15253/2175-6783.2014000600005

22. Soto-Fuentes P, Grandon KR, Santana DM, Yanez OJ. [Skills for nurses in the field of management and administration: contemporary challenges to the profession]. Aquichán [Internet]. 2014 [cited 2017 Aug 08];14(1):79-99. Available from: http://www.redalyc.org/ pdf/741/74130041008.pdf Spanish. 
23. Rothbarth S, Wolff LDG, Peres AM. [Developing nursing managerial competencies from the perspective of nursing administration professor]. Texto Contexto Enferm [Internet]. 2009 [cited 2018 May 23];18(2):321-9. Available from: http://dx.doi.org/10.1590/S010407072009000200016 Portuguese.

24. Mesquita SKC, Meneses RMV, Ramos DKR. [Active teaching / learning methodologies: difficulties faced by the faculty of a nursing course]. Trab Educ Saúde [Internet]. 2016 [cited 2017 Aug 08];14(2):473-86. Available from: http://dx.doi.org/10.1590/1981-7746-sip00114 Portuguese.

25. Soares MI, Camelo SHH, Resck ZMR, Terra FS. Nurses' managerial knowledge in the hospital setting. Rev Bras Enferm [Internet]. 2016 [cited 2018 Feb 12];69(4):676-683. Available from: doi: http://dx.doi.org/10.1590/0034-7167.2016690409i 